\title{
Developing a new scissor for cleft surgery: The cleft palate dissection scissor
}

Sir,

We hereby describe a recently developed cleft surgery scissor. The main objective was to ease preparation of the oral mucosa during operation with its unique design.

Nowadays, for almost all surgical interventions, technical solutions have been already established. ${ }^{[1]}$ Only in a few situations, special instruments should be used. One of such situation is the dissection of the soft tissue of the hard and soft palate in infants with a cleft. With a palate in more sagittal position, dissection could be somewhat frustrating. The risk of pinprick lesions increases during preparation because of limited oral space to separate the different layers of the soft tissue with therefore a greater consecutive risk of fistulas. We hereby describe our new cleft dissection scissor to simplify the preparation.

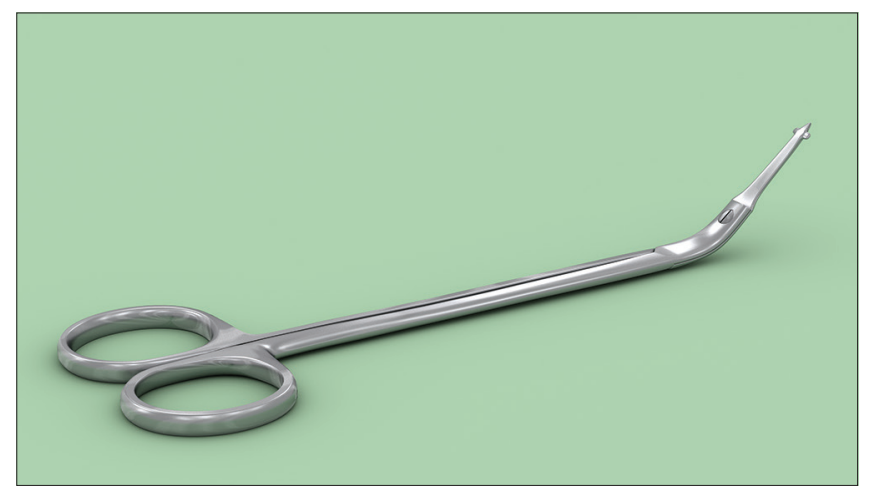

Figure 1: Oblique view of the scissor

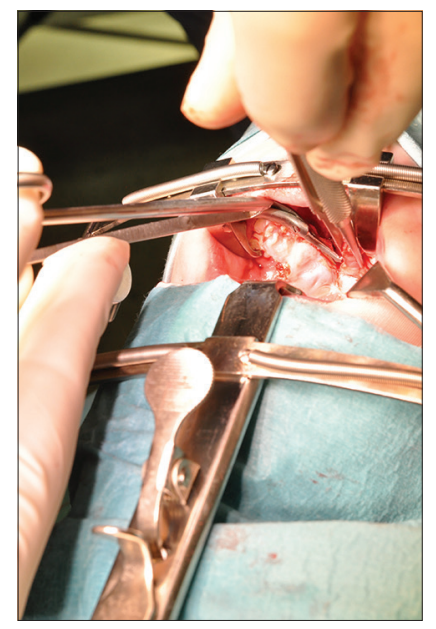

Figure 3: Scissor shown during operation
The two most important advantages in comparison to other dissection scissors are the unique "jet wing" tip design [Figures 1 and 2] in combination with the angled base of the scissor. Both have been developed to minimize the risk of perforation of the palatal mucosa during separation from the maxilla or the muscle and to get easily to the site [Figure 3]. The tip of the scissor is blunt to minimize the risk of penetrating the oral or nasal mucosa. During preparation, the fragile mucosal tissue can easily glide over the tip of the scissor because the surrounding tissue will be supported through the two small lateral wings of the tip with a length of $2 \mathrm{~mm}$ [Figure 4].

The new scissor with its unique tip design will facilitate operations in patients with a cleft of the hard or soft palate, especially in premature patients with palatal shelves often in a more sagittal orientation.

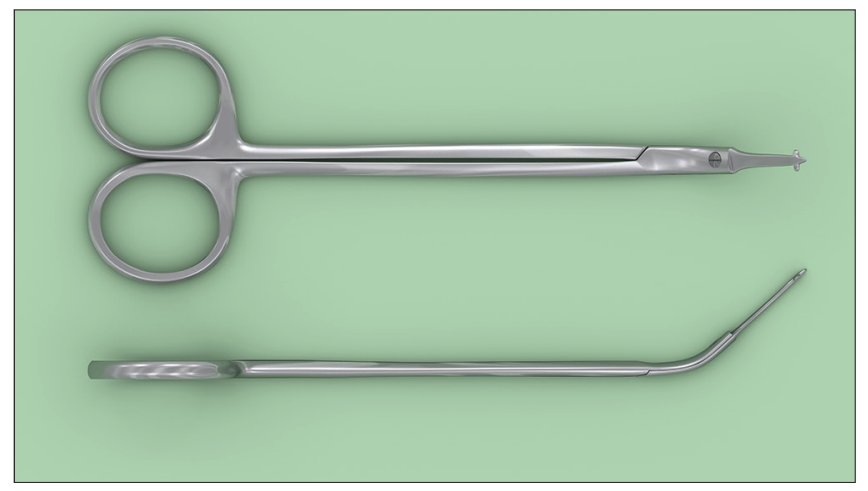

Figure 2: Top and lateral view of the scissor

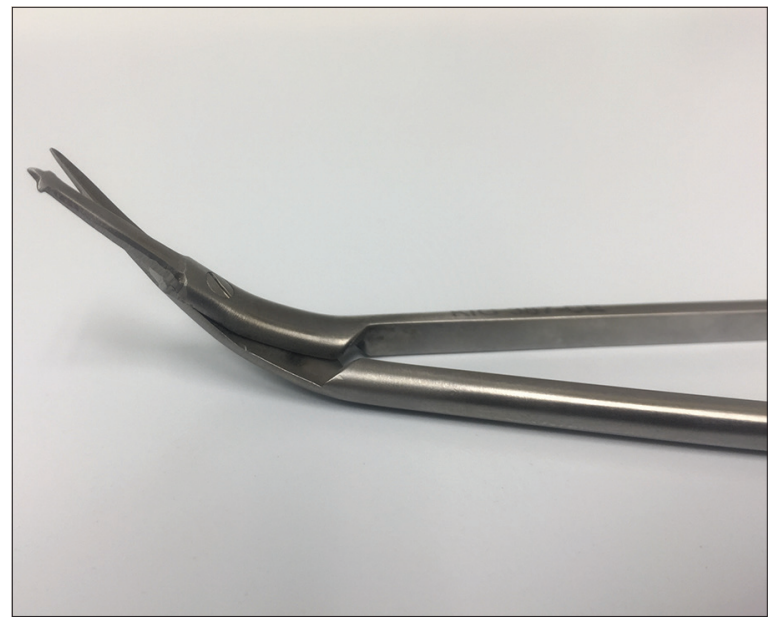

Figure 4: Tip of the scissor in detail 


\section{Acknowledgment}

The author would like to specially acknowledge Prof. D. Ulrich for his support.

\section{Financial support and sponsorship}

Nil.

\section{Conflicts of interest}

There are no conflicts of interest.

Till Wagner Radboud University Medical Center, 6500 HB Nijmegen, The Netherlands

Address for correspondence: Dr. Till Wagner, Radboud University Medical Center, Geert Grooteplein-Zuid 10, 6500 HB Nijmegen, The Netherlands. E-mail: till.wagner@Radboudumc.nl

\section{REFERENCE}

1. Pérez-Ruiz L, Herrerias-González F, Mele-Olive J, Gas-Ruiz C.
A simple modified scissor for combined dissection, cut and ligation. Acta Chir Belg 2009;109:655-6.

This is an open access article distributed under the terms of the Creative Commons Attribution-NonCommercial-ShareAlike 3.0 License, which allows others to remix, tweak, and build upon the work non-commercially, as long as the author is credited and the new creations are licensed under the identical terms.

\begin{tabular}{|l|l|}
\hline \multicolumn{2}{|c|}{ Access this article online } \\
\hline Quick Response Code: & Website: \\
www.jclpca.org \\
\cline { 2 - 2 }
\end{tabular}

Cite this article as: Wagner T. Developing a new scissor for cleft surgery: The cleft palate dissection scissor. J Cleft Lip Palate Craniofac Anomal 2017;4:170-1.

() 2017 Journal of Cleft Lip Palate and Craniofacial Anomalies | Published by Wolters Kluwer-Medknow 